\title{
Päästökauppa ja sen vaikutukset sähkön hintaan
}

\author{
Ismo Makkonen \\ Seinäjoen ammattikorkeakoulu, Elintarvike- ja maatalous \\ Kalevankatu 35, 60100 Seinäjoki \\ ismo.makkonen@seamk.fi
}

\section{TIIVISTELMÄ}

Päästökauppa on osa laajempaa päästökauppajärjestelmää, jonka tarkoituksena on vähentää kasvihuonekaasupäästöjä Euroopan unionin alueella aiheuttamalla lisäkustannuksia voimalaitoksille, jotka käyttävät fossiilisia polttoaineita. Päästökauppajärjestelmässä päästöjen vapautumiselle on asetettu katto, mikä määrittää kuinka monta hiilidioksiditonnia kasvihuonekaasuja päästökaupan piiriin kuuluvat laitokset saavat aiheuttaa. Laitokset voivat ostaa päästöoikeuksia markkinoilta, mikäli niille jaetut päästöoikeudet eivät riitä kattamaan niiden aiheuttamia päästöjä. Laitosten on myös mahdollista myydä niille jaettuja päästöoikeuksia toisille laitoksille, mikäli ne eivät tarvitse kaikkia oikeuksia. Kaikki EU:n jäsenmaat ovat mukana päästökaupassa ja Suomessa päästökaupan piiriin kuuluu noin 600 energiantuotanto- ja teollisuuslaitosta. Koko EU:n alueella päästökauppa koskee noin 12000 laitosta, joiden aiheuttamat päästöt ovat noin puolet EU-maiden aiheuttamista hiilidioksidipäästöistä.

Päästökauppakaudet on jaettu kolmeen velvoitekauteen, joiden aikana päästökaupan ehdot ja vaatimukset kiristyvät siirryttäessä päästökauppakaudelta toiselle. Ensimmäinen päästökauppakausi käsitti vuodet 2005 - 2007, toinen päästökauppakausi vuodet 2008 - 2012 ja kolmas päästökauppakausi käsittää vuodet 2013 - 2020. Neljännen päästökauppakauden ehdoista ei ole vielä sovittu, mutta päästökauppa tulee jatkumaan direktiivin mukaan myös vuoden 2020 jälkeen. Ensimmäisellä ja toisella päästökauppakaudella direktiivi koski vain hiilidioksidipäästöjä, koska järjestelmä haluttiin pitää mahdollisimman yksinkertaisena. Kolmannella päästökauppakaudella päästökauppaa käydään kaikilla kasvihuonekaasuilla, joita ovat hiilidioksidin lisäksi metaani, typpioksiduuli, fluori- ja perfluorihiilivedyt ja rikkiheksafluoridi.

Tutkimuksen aineistona on käytetty päästökauppaa ja ilmastonmuutosta käsittelevää kirjallisuutta ja alan tutkimuksia. Sähkön tuotantokustannuksien laskelmien teossa on käytetty apuna tutkimusta sähkön tuotantokustannuksista. Laskelmia on tarkennettu vastaamaan tämän hetkisiä sähkön tuotantokustannuksia. Sähkön tuotantokustannuksien vertailuun otettiin tässä tutkimuksessa mukaan myös vesivoima.

Maataloussektorin suorat kasvihuonekaasupäästöt eivät vielä kuulu päästökaupan piiriin, mutta epäsuorasti päästökauppa vaikuttaa maatalouden kannattavuuteen sähkön hinnan kautta. Päästökaupan aiheuttamasta sähkön hinnannoususta johtuen teollisuuden tuotantokustannukset ovat nousseet. Nämä ovat siirtyneet tuotteiden hintoihin sekä heikentäneet suoraan maatilojen kannattavuutta. Sähkön markkinahinta määräytyy kalleimman tarvittavan varavoimalaitoksen rajakustannuksen mukaan. Sähkön tuottaminen on kalleinta puusta ja fossiilisista polttoaineista, mutta edullisinta vesi-, ydin- ja tuulivoimasta.

Asiasanat: päästökauppa, sähkön hinta, kasvihuonekaasupäästöt, kustannukset 


\section{Johdanto}

Euroopan unionin jäsenmaat ovat sitoutuneet vähentämään kasvihuonekaasupäästöjään 20 prosenttia vuoden 1990 tasosta vuoteen 2020 mennessä. Vuonna 2003 Euroopan unionissa säädettiin direktiivi kasvihuonekaasujen päästöoikeuksien kaupasta (2003/87/EY), jonka tarkoituksena on vähentää kasvihuonekaasupäästöjä ja auttaa Euroopan unionia saavuttamaan omat tavoitteet sekä Kioton pöytäkirjan velvoitteet ilmastonmuutoksen pysäyttämiseksi. (Euroopan unionin....2012, Ilmasto-oikeus 2011).

Päästökaupan tarkoituksena on vähentää fossiilisten polttoaineiden käyttöä ja edistää uusiutuvien energiamuotojen käyttöönottoa. Tällä hetkellä päästökaupan vaikutus fossiilisten polttoaineiden käyttöön on päinvastainen. Uusiutuvien energiamuotojen kilpailukyky fossiilisia polttoaineita vastaan on matalan päästöoikeuden ansiosta olematon. Päästökaupan piiriin kuuluvat kaikki yli $20 \mathrm{MW}$ suuremmat polttolaitokset ja samaan kaukolämpöverkkoon kytketyt pienemmät laitokset, joiden yhteenlaskettu teho on vähintään 20 MW.

Suomelta jäi käyttämättä päästöoikeuksia ensimmäiseltä päästökauppakaudelta noin $13 \%$, koska päästöt alittivat ilmaiseksi jaettujen päästöoikeuksien määrän. Euroopan unionin jäsenmaiden tuli alittaa toisen päästökauppakauden päätteeksi Kioton ilmastosopimuksessa määritetyn kunkin valtion vuoden 1990 päästötaso. Suomen päästöjen tavoitetaso on 70,3 $\mathrm{MtCO}_{2}$ vuodessa. Suomi saavutti tavoitteen ja toisen päästökauppakauden päätteeksi kokonaispäästöt olivat noin 5 prosenttia tavoitetasoa pienemmät. Päästökauppasektorilla tavoitteena on vähentää kasvihuonekaasupäästöjä kolmannella päästökauppakaudella 21 prosenttia vuoden 2005 tasosta vuoteen 2020 mennessä (Suomen kasvihuonekaasupäästöt...2012).

Päästöoikeuden hinta muodostuu kysynnän ja tarjonnan mukaan. Päästökaupassa yhden ympäristöön päästetyn hiilidioksiditonnin hinta on vaihdellut paljon. Päästökaupan alettua päästöoikeus maksoi noin 30 euroa tonnilta, mutta päästöoikeuksien ylitarjonnan vuoksi päästöoikeuden hinta on laskenut jopa lähelle $0 € / \mathrm{tCO}_{2}$. Päästöoikeuden hinta oli kolmannen päästökauppakauden alussa tammikuussa 2013 noin $7 € / t C O 2$, mutta hinta laski marraskuussa alle $5 € / t C O 2$. Päästöoikeuden hinta vaikuttaa yritysten päästöjen vähentämistoimenpiteisiin. Yritykset eivät vähentäisi päästöjään, mikäli oikeudet jaettaisiin aina ilmaiseksi. Päästökaupalla on vaikutusta yritysten kilpailukykyyn ja tuotteiden hintoihin. Tuotteiden hinnoittelussa on otettava huomioon päästökaupan aiheuttama lisäkustannus tavanomaisten tuotantokustannusten lisäksi. Päästökaupan myötä joitakin tuotteita tai palveluja voi olla kannattamatonta tuottaa. Päästöoikeuden aiheuttama lisäkustannus siirtyy kokonaan esimerkiksi sähkön hintaan. Päästökaupan aiheuttama lisäkustannus fossiilisille ja hitaasti uusiutuville polttoaineille muodostuu niiden käytöstä aiheutuvien hiilidioksidipäästöjen määrästä. Mitä enemmän kasvihuonekaasupäästöjä aiheutuu, sitä korkeampi on päästökaupan aiheuttama lisäkustannus. Sähköntuotannossa polttoaineiden hinnat ovat verottomia, kun lämmöntuotannossa hinnat ovat verollisia (EU:n päästökaupan...2004, Laimi 2006, EU:n päästökaupan 3. kausi...2012, Hallivuori 2012, Sähkömarkkinaraportti 2013).

Päästökauppa aiheuttaa epävarmuutta yritysten investointihalukkuuteen. Päästöoikeuksien markkinahintojen heilahtelu vaikeuttaa hintojen kehityksen arvioimista, minkä takia investointien tekeminen on riskialtista. Ilmaiseksi jaettavien päästöoikeuksien lukumäärä vaikuttaa myös paljon yritysten investointihalukkuuteen. Sähkön, maakaasun ja puupolttoaineiden markkinahinnat reagoivat, mikäli päästöoikeuksien markkinahinta muuttuu. Tästä johtuen investointien tekeminen on riskialtista (Linnainmaa ym. 2005).

Tässä tutkimuksessa keskitytään selvittämään yleisellä tasolla päästöoikeuden hinnan muodostuminen Suomessa ja päästökaupan vaikutus sähkön hintaan eri polttoaineilla. Lisäksi työssä haluttiin selvittää sähköntuotannossa käytettävien kotimaisten polttoaineiden tämänhetkinen kilpailukyky energiamarkkinoilla. Erityisesti Suomen merkittävimmän uusiutuvan polttoaineen puun asema sähköntuotannossa haluttiin saada selville.

\section{Aineisto ja menetelmät}

Tutkimus toteutettiin keräämällä aineistoa kirjallisuudesta, alan tutkimuksista ja haastattelemalla Ete-lä- ja Keski-Pohjanmaalla sijaitsevien kahden merkittävän voimalaitoksen toimihenkilöitä. Tutkimuk-sen laskelmat tehtiin aiempien tutkimuksien pohjalta ja ne ovat suuntaa antavia. Sähkön tuotantokus-tannusten laskelmien teossa on käytetty apuna Tarjanteen ja Kivistön (2012) tutkimusta sähkön tuotan- 
tokustannusvertailusta. Laskelmia on tarkennettu vastaamaan tämänhetkisiä sähkön tuotantokustannuksia. Sähkön tuotantokustannuksien vertailuun otettiin tässä tutkimuksessa mukaan myös vesivoima, joka ei ollut mukana Tarjanteen ja Kivistön tutkimuksessa.

Ydinvoiman sähköteho, investointikustannus ja polttoaineen hinta arvioitiin rakenteilla olevan olkiluodon kolmannen reaktorin tietojen pohjalta (Olkiluoto 3... 2012, Olkiluoto 3:sta...2013). Sähkön tuotantokustannuksien laskelmissa vesivoiman kustannustiedot kerättiin vesivoimaa käsittelevistä tutkimuksista (Hydropower 2010). Suomessa sijaitsevien vesivoimalaitosten investointikustannuksia on vaikea arvioida, koska uusia suuria yli 20 MW vesivoimalaitoksia ei ole rakennettu 1970-luvun jälkeen (Vesivoimalat Suomessa 2012). Tässä tutkimuksessa käytetyt sähkön ja lämmön eri tuotantomuotojen polttoainekustannukset selvitettiin Tilastokeskuksen aineistoista (Energian hinnat...2013). Yleisesti voimalaitosten rakennuskustannukset ovat pysyneet viime vuosina tasaisina, johtuen maailmanlaajuisesta lamasta.

Rakennuskustannusten nousu arvioitiin Tilastokeskuksen rakennuskustannuksien hintakehityksen mukaan (Rakennuskustannusindeksi 2013). Käyttö- ja kunnossapitokustannukset saatiin vesivoimaa lukuun ottamatta Tarjanteen ja Kivistön (2012) tutkimuksesta. Ydinvoiman taloudellinen elinikä arvioitiin tässä tutkimuksessa 60 vuodeksi ja vesivoiman 70 vuodeksi. Molempia sähköntuotantomuotoja voidaan kuitenkin käyttää kauemmin. Kaikkien muiden sähköntuotantomuotojen elinikä arvioitiin Tarjanteen ja Kivistön (2012) tutkimuksen pohjalta 25 vuodeksi. Huippukäyttöajaksi arvioitiin vuodessa Tarjanteen ja Kivistön (2012) mukaan tuulivoimalle 2200 tuntia sekä muille paitsi vesivoimalle 8000 tuntia. Vesivoiman huippukäyttöajaksi arvioitiin 5000 tuntia Suomen vesivoimalaitosten vuotuisten sähköntuotantomäärien pohjalta (Vesivoimalat Suomessa 2012). Puu- ja tuulivoimalaitosten valtiolta saamia tukia ei ole otettu huomioon laskelmissa eikä eri voimalaitoksiin kohdistuvia veroja.

\section{Tulokset ja tulosten tarkastelu}

Päästöoikeuden hinnalla on merkittävä vaikutus sähköntuotannon kustannuksiin polttoainekustannusten kautta. Fossiiliset ja hitaasti uusiutuvat polttoaineet hyötyvät matalasta päästöoikeuden hinnasta, jolloin niiden kustannukset ovat edullisemmat. Uusiutuvat polttoaineet hyötyvät korkeasta päästöoikeuden hinnasta, koska niiden kustannuksiin päästökaupalla ei ole vaikutusta. Päästökaupan aiheuttama lisäkustannus fossiilisille ja hitaasti uusiutuville polttoaineille muodostuu niiden käytöstä aiheutuvien hiilidioksidipäästöjen määrästä. Mitä enemmän kasvihuonekaasupäästöjä aiheutuu, sitä korkeampi on päästökaupan aiheuttama lisäkustannus. Taulukko1 havainnollistaa kuinka paljon hiilidioksidipäästöjä eri polttoaineiden käytöstä aiheutuu ja kuinka paljon päästöoikeuden hinnannousu vaikuttaa niiden kustannuksiin. Turpeen ja kivihiilen kustannukset kärsivät kaikkein eniten päästöoikeuden hinnannoususta. Vähärikkisen raskaan polttoöljyn ja kevyen polttoöljyn poltosta aiheutuvat hiilidioksidipäästöt ovat hieman turpeen ja kivihiilen käytöstä aiheutuvia päästöjä pienemmät. Maakaasu on yleisimmin käytetyistä uusiutumattomista polttoaineista vähäpäästöisin. Puu on hiilidioksidineutraali polttoaine, koska sen poltosta aiheutuva hiilidioksidi sitoutuu kasvavaan metsään.

Taulukko1. Päästöoikeuden vaikutus polttoaineiden hintaan.

\begin{tabular}{|c|c|c|c|c|c|c|c|}
\hline \multirow[t]{2}{*}{ Polttoaine } & \multirow{2}{*}{$\begin{array}{c}\text { Hiilidioksidi } \\
\text { päästöt, } \\
\mathrm{CO}_{2} \\
\text { (t/MWh) }\end{array}$} & \multirow{2}{*}{\begin{tabular}{|c|} 
Polttoaineen \\
veroton \\
hinta \\
(€/MWh)
\end{tabular}} & \multicolumn{4}{|c|}{ Päästöoikeuden aiheuttama lisäkustannus } & \multirow[b]{2}{*}{$\begin{array}{l}30 € / \mathrm{tCO}_{2} \\
(€ / \mathrm{MWh})\end{array}$} \\
\hline & & & $\begin{array}{l}2 € / \mathrm{tCO}_{2} \\
(€ / \mathrm{MWh})\end{array}$ & $\begin{array}{l}5 € / \mathrm{tCO}_{2} \\
(€ / \mathrm{MWh})\end{array}$ & $\begin{array}{l}10 € / \mathrm{CCO}_{2} \\
(€ / \mathrm{MWh})\end{array}$ & $\begin{array}{l}20 € / \mathrm{tCO} 2 \\
(€ / \mathrm{MWh})\end{array}$ & \\
\hline Turve & 0,382 & 13,2 & 0,8 & 1,9 & 3,8 & 7,6 & 11,5 \\
\hline Kivihiili & 0,341 & 9,3 & 0,7 & 1,7 & 3,4 & 6,8 & 10,2 \\
\hline Raskas polttoöljy (vähä rikkinen) & 0,279 & 39,0 & 0,6 & 1,4 & 2,8 & 5,6 & 8,4 \\
\hline Kevyt polttoöljy & 0,267 & 52,0 & 0,5 & 1,3 & 2,7 & 5,3 & 8,0 \\
\hline Maakaasu & 0,202 & 34,8 & 0,4 & 1,0 & 2,0 & 4,0 & 6,1 \\
\hline Metsähake & 0 & 20,4 & 0,0 & 0,0 & 0,0 & 0,0 & 0,0 \\
\hline
\end{tabular}

Taulukossa 2 on eri voimalaitosten arvioidut sähköntuotannon käyttö- ja kustannustiedot. Ydinvoima on kaikkein tehokkain sähköntuotantomuoto, mutta samalla se on investointikustannuksiltaan selkeästi kallein. Hiilivoima on sähköteholtaan toiseksi tehokkain ja myös kustannuksiltaan toiseksi 
kallein. Kaasuvoima on kolmanneksi tehokkain sähköntuotannossa ja se on samalla kolmanneksi kallein. Puu- ja turvevoiman rakentaminen on lähes yhtä kallista ja niiden sähköteho on tässä vertailussa sama. Vesivoiman rakentaminen on tässä vertailussa toiseksi edullisinta ja sen sähköteho on toiseksi pienin. Tuulivoiman investointikustannus on vertailun edullisin, mutta sähköteho on myös vertailun heikoin.

Taulukko 2. Voimalaitosten käyttö- ja kustannustiedot.

\begin{tabular}{|c|c|c|c|c|c|c|c|}
\hline & YDIN & KAASU & HIILI & TURVE & PUU & TUULI & VESI \\
\hline SÄHKÖTEHO [MW] & 1600 & 400 & 500 & 150 & 150 & 3 & 100 \\
\hline VUOSIHYÖTYSUHDE [\%] & $37,00 \%$ & $58,00 \%$ & $42,00 \%$ & $40,00 \%$ & $33,00 \%$ & - & $85,00 \%$ \\
\hline INVESTOINTIKUSTANNUS [MIL. €] & 8500 & 425 & 900 & 300 & 320 & 4 & 218 \\
\hline $\begin{array}{l}\text { OMINAISINVESTOINTIKUSTANNUS } \\
{[€ / \mathrm{kW}]}\end{array}$ & 5313 & 1063 & 1800 & 2000 & 2133 & 1400 & 2180 \\
\hline POLTTOAINEEN HINTA [€/MWh] & 1,9 & 34,8 & 9,3 & 13,2 & 20,4 & 0 & 0 \\
\hline $\begin{array}{c}\text { SÄHKÖNTUOTANNON } \\
\text { POLTTOAINEKUSTANNUS [€/MWh } \\
\text { sähkö] }\end{array}$ & 5,1 & 60,0 & 22,14 & 33,0 & 61,82 & 0 & 0 \\
\hline $\begin{array}{c}\text { KÄYTTÖ- JA } \\
\text { KUNNOSSAPITOKUSTANNUKSET } \\
\text { [€/MWh] }\end{array}$ & 19 & 8 & 11 & 11 & 7 & 10 & 7 \\
\hline $\begin{array}{c}\text { KÄYTTÖ- JA KUNNOSSAPIDON OSUUS } \\
\text { KUSTANNUKSISTA }\end{array}$ & $2,90 \%$ & $5,70 \%$ & $4,90 \%$ & $4,20 \%$ & $2,60 \%$ & $1,70 \%$ & $1,50 \%$ \\
\hline MUUTTUVIEN K\&K-KUST. OSUUS [\%] & $50 \%$ & $65 \%$ & $70 \%$ & $50 \%$ & $40 \%$ & $40 \%$ & $50 \%$ \\
\hline TALOUDELLINEN ELINIKÄ [a] & 60 & 25 & 25 & 25 & 25 & 25 & 70 \\
\hline REAALIKORKO [\%] & $5,00 \%$ & $5,00 \%$ & $5,00 \%$ & $5,00 \%$ & $5,00 \%$ & $5,00 \%$ & $5,00 \%$ \\
\hline ANNUITEETTITEKIJÄ [\%] & $5,28 \%$ & $7,10 \%$ & $7,10 \%$ & $7,10 \%$ & $7,10 \%$ & $7,10 \%$ & $7,10 \%$ \\
\hline PÄÄSTÖOIKEUDEN HINTA [€/t CO2] & 30 & 30 & 30 & 30 & 30 & 30 & 30 \\
\hline HUIPPUKÄYTTÖAIKA [h/a] & 8000 & 8000 & 8000 & 8000 & 8000 & 2500 & 5000 \\
\hline KÄYTTÖKERROIN [\%] & $91,3 \%$ & $91,3 \%$ & $91,3 \%$ & $91,3 \%$ & $91,3 \%$ & $25,1 \%$ & $80,0 \%$ \\
\hline PÄÄOMAKUSTANNUS [€/MWh] & 35,1 & 9,4 & 16,0 & 17,7 & 18,9 & 39,7 & 31,0 \\
\hline
\end{tabular}

Kaikkien muiden polttoainekäyttöisten sähköntuotantomuotojen paitsi kivihiilen ja ydinvoiman polttoainekustannukset ovat nousseet verrattuna aiempiin tutkimuksiin. Kaasuvoiman polttoainekustannus on tässä tutkimuksessa selkeästi kallein. Kaasuvoiman polttoainekustannus on noussut reilussa vuodessa noin $5 € / M W h$. Puuvoiman polttoainekustannus on tämän vertailun toiseksi kallein. Puuvoiman polttoainekustannus on noussut reilussa vuodessa noin $2 € / M W h$. Turvevoiman polttoainekustannus on kolmanneksi edullisin. Turvevoiman polttoainekustannus on noussut reilussa vuodessa noin $3 € / M W h$. Kivihiilivoiman polttoainekustannus on vertailun toiseksi edullisin. Kivihiiltä käytetään energiantuotannossa tällä hetkellä enemmän kuin koskaan aiemmin 2000-luvulla, koska sen kustannukset ovat ennätyksellisen alhaalla. Kivihiilen polttoainekustannus on laskenut reilussa vuodessa noin 2,7 €/MWh. Ydinvoiman polttoainekustannus on vertailun edullisin. Tuuli- ja vesivoimalle ei aiheudu polttoainekustannuksia.

Käyttö- ja kunnossapitokustannuksilta ydinvoima on selkeästi kallein. Hiili- ja turvevoiman käyttö- ja kunnossapitokustannukset ovat yhtä kalliita. neljänneksi kallein käyttö- ja kunnossapitokustannus on tuulivoimalla. Kaasuvoiman käyttö- ja kunnossapitokustannukset ovat kolmanneksi edullisimmat. Puuvoiman käyttö- ja kunnossapitokustannukset ovat vertailun toiseksi edullisimmat. Vesivoiman käyttö- ja kunnossapitokustannukset ovat edullisimmat.

Tämän tutkimuksen laskelmissa (kuva 1) kaikkein edullisimmat sähkön tuotantokustannukset ovat vesivoimalla. Toiseksi edullisin sähköntuotantomuoto on yllättäen hiilivoima, jonka kustannukset ovat laskeneet aiempien tutkimuksien laskelmista. Kolmanneksi edullisin sähköntuotantomuoto tässä tutkimuksessa on tuulivoima. Neljänneksi edullisimmat sähkön tuotantokustannukset on ydinvoimalla, jonka kustannukset ovat nousseet selvästi aiempien tutkimuksien laskelmista.. Turvevoiman sähkön tuotantokustannukset ovat vertailun kolmanneksi kalleimmat. Toiseksi kallein sähköntuotantomuoto on kaasuvoima. Kaikkein kallein sähköntuotantomuoto on puusähkö. Puusähkön kustannuksissa ei ole otettu huomioon puuhakkeelle myönnettyä tuotantotukea, joka on nykyisellä alhaisella päästöoikeuden 
hinnalla ( $\left.<10 € / \mathrm{tCO}_{2}\right)$ 13,3 €/MWh. Puusähkön hinnaksi muodostuu tuotantotuen myötävaikutuksella 74,4 €/MWh. Tämä hinta pätee ainoastaan puuhaketta käyttäville laitoksilla.

Pääomakustannus muodostaa suurimman osan ydin, tuuli- ja vesivoiman kustannuksista. Hiili, puu- ja turvevoiman pääomakustannukset ovat samaa hintaluokkaa. Pienin pääomakustannus on kaasuvoimalla. Pääomakustannukset ovat samaa luokkaa aiempien tutkimuksien kanssa ydinvoimaa lukuun ottamatta, jonka pääomakustannukset ovat nousseet.

Puulla tuotetun sähkön hinta on noussut kaikkein eniten, kun verrataan tämän tutkimuksen tuloksia aiempiin tutkimuksiin. Sähkön hinnan nousu on johtunut pääasiassa eri polttoaineiden kustannusten kasvamisesta. Puusähkön hinta on noussut noin kahdessa vuodessa lähes $17 € / M W h$. Samassa ajassa kaasusähkön hinta on noussut $10 €$ /MWh ja turvesähkön noin 8,2 €/MWh. Hiilisähkö on ainut sähkön tuotantomuoto, jonka kokonaiskustannukset eivät ole nousseet, vaikka polttoaine- ja rakennuskustannukset ovatkin kasvaneet.

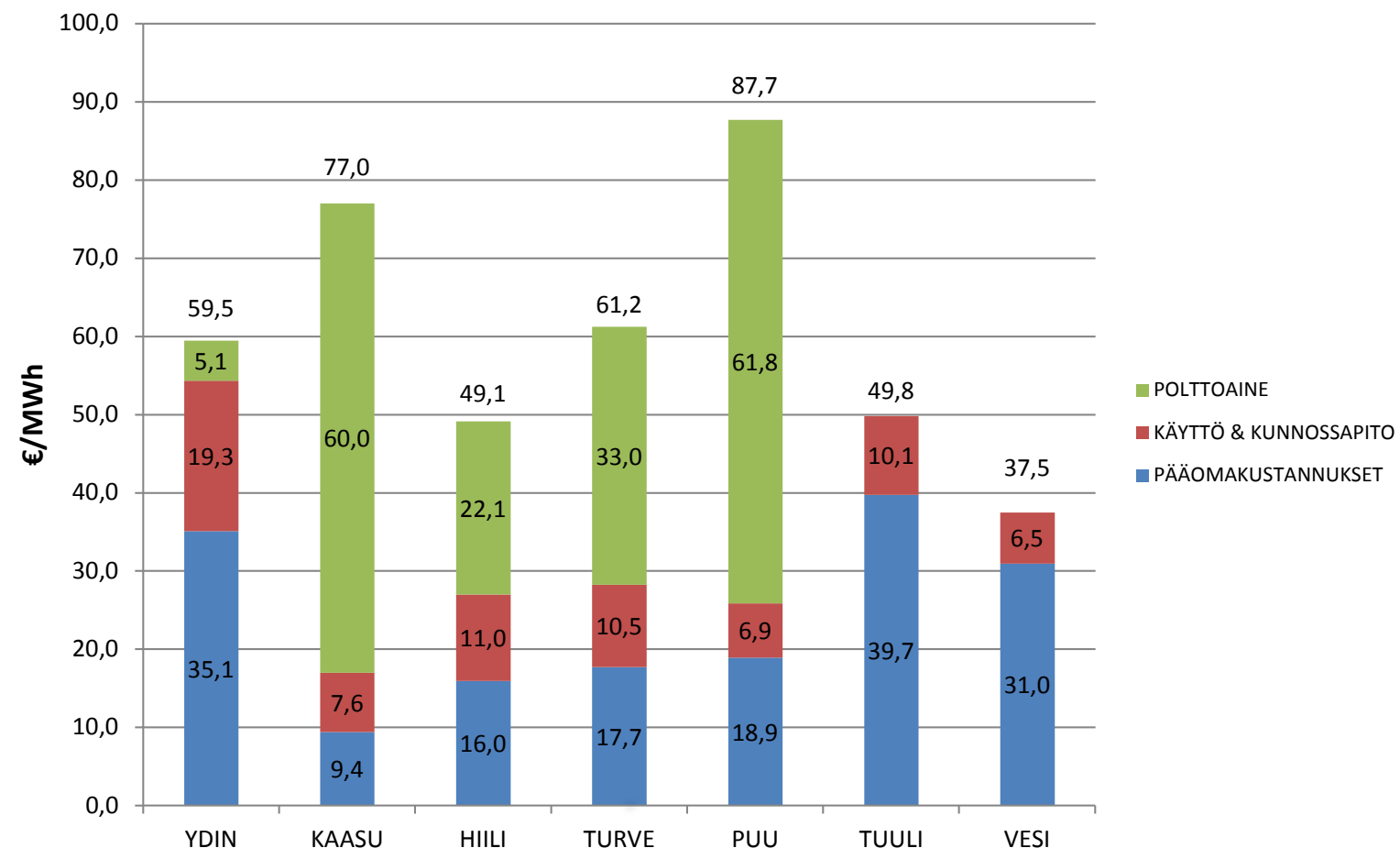

Kuva 1. Sähkön eri tuotantomuotojen tuotantokustannukset ilman päästökauppaa.

Kuvassa 2 on esitetty sähkön tuotantokustannukset eri sähköntuotantomuodoille, kun päästökaupan vaikutus on otettu huomioon kustannuksissa. Päästöoikeuden hintana on käytetty kuvan 2 laskelmissa $30 € / \mathrm{tCO}_{2}$, mihin päästöoikeuden hinnan on tulevaisuudessa arvioitu nousevan. Tällä hetkellä päästöoikeuden hinta on noin $7 € / M W h$, jolla ei ole juuri hiilidioksidipäästöjä alentavaa vaikutusta. Kuvasta 2 voidaan havaita, että päästökauppa aiheuttaa suurimman lisäkustannuksen eniten hiilidioksidipäästöjä aiheuttavalle turvetta polttavalle turvevoimalaitokselle. Toiseksi eniten päästökauppa aiheuttaa lisäkustannuksia kivihiiltä polttavalle hiilivoimalaitokselle. Kolmanneksi eniten päästökauppa aiheuttaa lisäkustannuksia maakaasua käyttävälle kaasuvoimalaitokselle. Päästökaupan aiheuttama lisäkustannus nostaa hiilivoiman kustannukset tuulivoiman kustannuksia korkeammiksi ydinvoiman tasolle. Päästökauppa kaventaa turve- ja kaasuvoiman sähköntuotantokustannusten etua puuvoimaan nähden. Kaasuvoimalla tuotettu sähkö ei ole kuin 4,6 €/MWh halvempaa kuin puuvoimalla tuotettu sähkö. Puuvoimalla tuotettu sähkö on lähes samanhintaista kuin turvevoimalaitoksessa tuotettu sähkö, kun otetaan huomioon puusähkön saama tuotantotuki. Tällöin turpeella tuotetun sähkön etu on vain $1,7 € /$ MWh puusähköön nähden. 


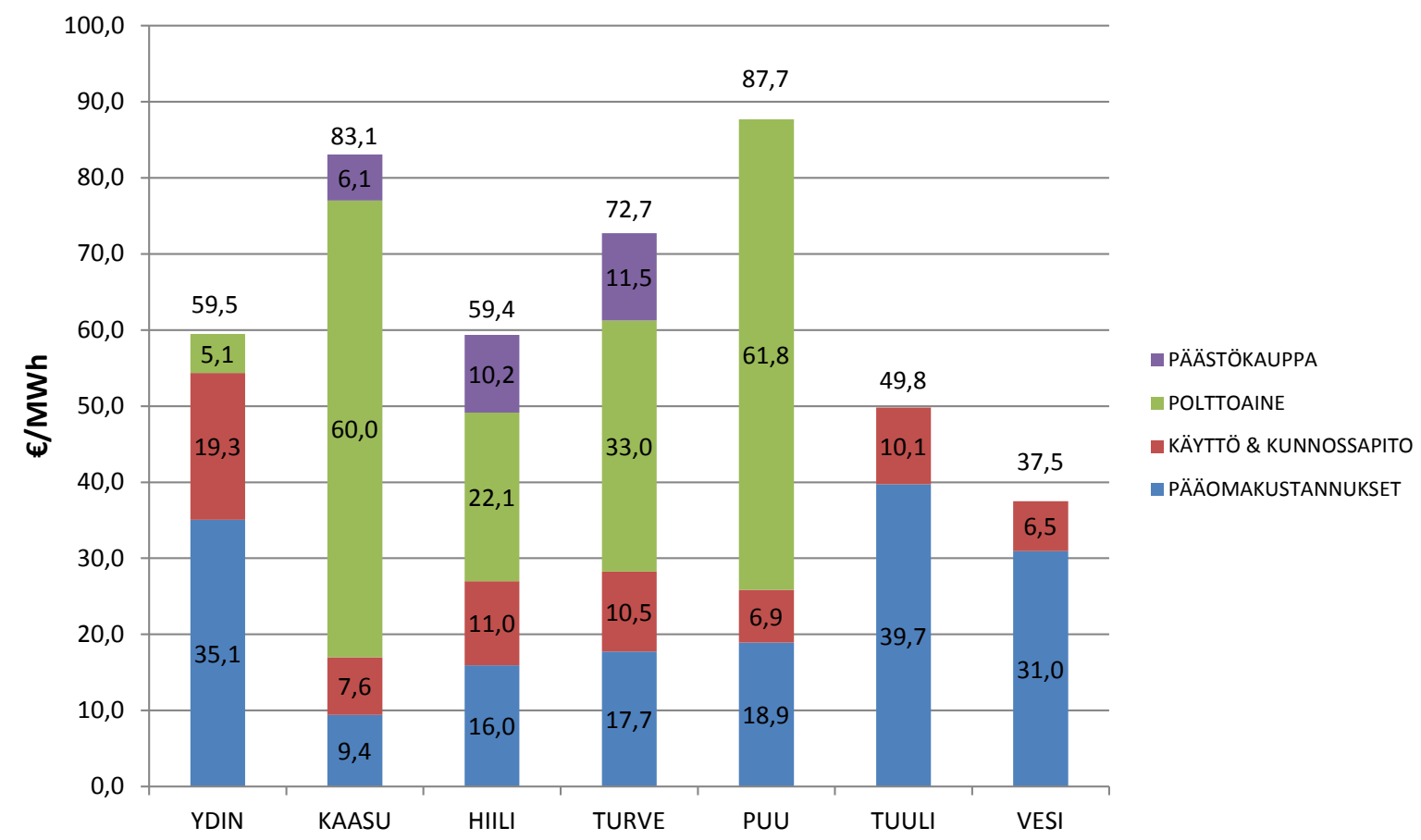

Kuva 2. Sähkön eri tuotantomuotojen tuotantokustannukset päästökaupassa.

\section{Johtopäätökset}

Kolmannen päästökauppakauden alussa korotettu turpeen vero, turpeen huono saatavuus, epävarma energiapuupolitiikka ja kivihiilen edullinen hinta kannustavat laitoksia panostamaan jatkossa yhä enemmän ulkomaisen energian käyttöön. Kivihiilen tuonti tulee lisääntymään, mikäli päästöoikeuden ja kivihiilen hinta pysyy matalana eikä kotimaisten polttoaineiden asemaa energiamarkkinoilla saada parannettua. Turpeen käyttö kärsii veronkorotuksista, mutta matala päästöoikeuden hinta ylläpitää sen kilpailukykyä suhteessa muihin polttoaineisiin. Turvetta tuotetaan Suomessa runsaasti, mutta alan kannattavuus on riippuvainen turpeen noston sääolosuhteista ja uusien turvesoiden luvista. Metsäenergian käyttö hyötyy runsaspäästöisten polttoaineiden veronkorotuksista ja korkeasta päästöoikeuden hinnasta, mutta haketustuen loppuminen on heikentänyt puun asemaa energiamarkkinoilla. Pienpuun energiatukijärjestelmän voimaantulon viivästyminen on myös heikentänyt metsähakkeen käyttöä.

Puupolttoaineilla tuotettavan sähkön kustannukset ovat hyvin korkeat johtuen osaksi siitä, että sähkön tuotannossa käytettävien polttoaineiden hinnat ovat verottomia. Lämmöntuotannossa puupolttoaineet ovat kilpailukykyisempiä. Tämän tutkimuksen pohjalta voidaan todeta, että puulla sähkön tuottaminen ei ole kovin kannattavaa nykyisellä päästöoikeuden hinnalla. Kustannukset ovat liian korkeat, vaikka puusta tuotetulle sähkölle maksetaankin tukea. Tehokkain ja halvin rakennettavissa oleva sähköntuotantomuoto pitkällä tähtäimellä on ydinvoima, vaikkakin sen kilpailukykyä on heikentänyt kohonneet rakennuskustannukset. Tässä tutkimuksessa käytettiin ydinvoiman laskelmien arvoina arvioituja Olkiluodon kolmannen reaktorin rakennuskustannusarvioita. Laskelmissa uusien ydinvoimaloiden rakennuskustannukset ovat nousseet niin suuriksi, ettei niissä tuotettu sähkö ole enää niin edullista, mitä se on aiemmin rakennetuissa ydinvoimaloissa. Lisäksi ydinvoimaloihin liittyy muita energiantuotantomuotoja suurempi riski mahdollisen ydinonnettomuuden tapahtuessa.

Päästöoikeuden hinnan romahtaminen toisen päästökauppakauden lopussa aiheutti päästöoikeuksien myyntipainetta johtuen markkinoilla vallitsevasta päästöoikeuksien ylitarjonnasta. Päästöoikeuden hinnan laskun takia kolmannen päästökauppakauden alussa puupolttoaineiden käyttö on vähentynyt ja kivihiilen ja tuontipuun käyttö on lisääntynyt energiakäytössä. 


\section{Kirjallisuus}

Energian hinnat 2. vuosineljännes. 2013. [Verkkodokumentti]. Tilastokeskus. Saatavissa: http://www.stat.fi/til/ehi/2013/02/ehi_2013_02_2013-09-18_fi.pdf.

EU:n päästökaupan, energiaverotuksen ja energiatuotannon tukien yhteensovittaminen. 2004. [Verkkodokumentti]. Kauppa- ja teollisuusministeriön julkaisuja 35/2004. Saatavissa: http://ktm.elinar.fi/ktm_jur/ktmjur.nsf/all/F5E0C0886CCF4749C2256F6A004AF890/\$file/jul35eos_2 004.pdf.

EU:n päästökaupan 3. kausi - mikä muuttuu? 2012 [Verkkodokumentti]. Elinkeinoelämän keskusliitto.

Saatavissa: http://www.ek.fi/ek/fi/energia_ym/toimittajaseminaariaineisto2012/Ruohomaki_EUn_paastokauppa.p df.

Euroopan unionin päästökauppa. 2012. [Verkkodokumentti]. Ympäristö ministeriö. Saatavissa: http://www.ymparisto.fi/default.asp?contentid=81079.

Hallivuori, J. 2012. Energiamarkkinakatsaus joulukuu 2012. [Verkkodokumentti]. Turku energia. Saatavissa: http://www.turkuenergia.fi/index.php?page=bb3267ec5104576520cbb67bb8ad2d3.

Hollo, E., Kuokkanen, T. \& Utter, R. 2011. Ilmasto-oikeus. Helsinki: Talentum media Oy. Suomen kasvihuonekaasupäästöt 1990-2010. 2012. [Verkkodokumentti]. Tilastokeskus. Saatavissa: http://tilastokeskus.fi/tup/khkinv/suominir_2012.pdf.

Hydropower. 2010. [Verkkodokumentti]. Iea Etsap. Saatavissa: http://www.iea-etsap.org/web/etechds/pdf/e07-hydropower-gs-gct.pdf.

Laimi, J. 2006. Päästökaupan vaikutukset sähkön hintaan. Vaasa: Vaasan yliopiston julkaisuja.

Linnainmaa, T., Mälkki, H. \& Laurikka, H. (toim) 2005. HAMKin julkaisuja 6/2005. Päästökauppaopas, Kaupankäynti EU:n päästöoikeuksilla. Hämeenlinna: Hämeen ammattikorkeakoulu.

Olkiluoto 3 -ydinvoimalan rakennusprojekti. 2012. [Verkkodokumentti]. Wikipedia. Saatavissa: http://fi.wikipedia.org/wiki/Olkiluoto_3_-ydinvoimalan_rakennusprojekti.

Olkiluoto 3:sta voi tulla maailman kallein rakennus. 2013. [Verkkodokumentti]. Aamulehti. Saatavissa:

http://www.aamulehti.fi/Kotimaa/1194854246201/artikkeli/olkiluoto+3+sta+voi+tulla+maailman+kall ein+rakennus.html

Rakennuskustannusindeksi. 2013. [Verkkodokumentti]. Tilastokeskus. Saatavissa: http://tilastokeskus.fi/til/rki/2013/10/rki_2013_10_2013-11-15_fi.pdf.

Sähkömarkkinaraportti. 2013. [Verkkodokumentti]. Vantaan Energia. Saatavissa: http://www.vantaanenergia.fi/fi/yritykset/sahkoiset_palvelut/Sivut/Sahkomarkkinaraportti.aspx.

Tarjanne, R. \& Kivistö, A. 2012. [Verkkodokumentti]. Sähkön tuotantokustannusvertailu. Saatavissa: https://www.doria.fi/bitstream/handle/10024/86304/S\%c3\%a4hk\%c3\%b6n\%20tuotantokustannusverta ilu\%20\%2c\%20tutkimusraportti\%2027\%2c\%202012.pdf?sequence=1.

Vesivoimalat Suomessa. 2012. [Verkkodokumentti]. Wikipedia. Saatavissa: http://fi.wikipedia.org/wiki/Vesivoimalat_Suomessa. 